\title{
IDENTIFICATION THE STUDENTS' PRONUNCIATION PROBLEMS IN PRONOUNCING -ED ENDING AT ENGLISH STUDY PROGRAM OF IAIN BONE
}

\author{
Nunu Wahyuni \\ Institut Agama Islam Negeri Bone, Indonesia \\ nhunuchazychazy@gmail.com \\ Muhammad Zuhri Dj. \\ Institut Agama Islam Negeri Bone, Indonesia \\ zuhristaindije@gmail.com \\ Hasriati Nur \\ Institut Agama Islam Negeri Bone, Indonesia \\ athynour@gmail.com
}

\begin{abstract}
This paper presents research about "Identification the Students' Pronunciation Problems in Pronouncing ed ending at English Study Program of IAIN Bone". The sample consists of 5 students at the third semester in IAIN Bone. This research uses qualitative method by analyzing data using observation and interview. This paper aims to show the problems that students faced in pronouncing the -ed ending words. The result showed that most of the students were difficult to pronounce the -ed ending words correctly. They did not know how to pronounce and differentiate the words with final -ed, -d, or -t. The problems encountered by the students in pronouncing -ed ending caused by their lack of knowledge of the pronunciation of -ed ending. It is also possible that they do not know the theory well, and they are not able to practice it orally. So, the researchers concluded that there are some problems affecting the students' ability to pronounce the - ed ending words. It because the students could not differentiate which one is final of $/ \mathrm{d} / \mathrm{id} / \mathrm{and} \mathrm{t} /$, the students also have lack of knowledge about -ed ending words.
\end{abstract}

Keywords—Identification; Pronunciation; Pronouncing - ed Ending

\section{INTRODUCTION}

According to Marza (2014:1) defined that spoken communication is grounded on the communicability not only determined by correct grammar and profuse vocabulary but also on the correct interplay between segmental and supra-segmental features making up pronunciation. According to Dal-ton \& Seidlhofer in Tlazalo and Basurto (2014:153) defined that pronunciation is the action of producing sounds of speech to communicate a message. For this reason, possessing a good pronunciation of the foreign language is vital in oral communication. In addition, they also said that it is important to recognize that foreign language students must aim at developing a good pronunciation but it does not mean that they have to sound exactly like a native speaker.

Pronunciation plays an important role in learning English. Learning pronunciation is quite difficult for Indonesian students since they have been used to speaking their mother tongue since childhood. The common problem of learning English pronunciation caused by the differences between the sound system of the two languages (Dewi, 2009:14). Setter (2008) said that like listening, pronunciation is sometimes neglected in the process of language teaching in favor of reading and writing, which are rather more likely to lead to success in examination in cultures which are much more focused on those media. However, it seems rather pointless to study a foreign language at all if one does not intend to communicate in with other 
speakers of that language and, to this end one must learn how to pronounce it in a way which can be understood by a variety of listeners.

In educational system, students often receive extensive grammar instruction at the early stage, but the pronunciation aspect of such grammar lesson is not always addressed (Murcia, et.al., 1996:266). Muslimah ( 2013:21) in the result of her research found that many students have some problems in pronunciation. They think to pronounce English is difficult thing to do. It is because their tongue is not used in pronouncing some words that they seldom pronounce. Based on the researcher's preliminary observation, the researcher found that many learners even English study program students of IAIN Bone often face some difficulties in pronouncing final clusters, especially those with-ed ending. Theoritically, the students may know the rules of pronouncing-ed ending properly, but they seem to find it difficult to pronounce it orally. Based on the explanation, the researchers would like to research about "Identification the Students' Pronunciation Problems in Pronouncing - ed ending at English Study Program of IAIN Bone".

\section{Review of Literature}

\section{A. Pronunciation}

Pronunciation refers to the production of sounds to make meaning. It includes attention to the particular sounds of a language (Segments), aspects of speech such as intonation, phrasing, stress, timing, rhythm (suprasegmental aspects), how the voice is projected (voice quality) and, in its broadest definition, attention to gestures and expressions that are closely related to the way we speak a language (Yates, 2002). Hakim (2012:1) also said that learning pronunciation is not a simple process of memorizing a number item that can be mapped on to another tongue. It is true that pronunciation has important role in oral communication. If someone speaks in appropriate pronunciation, the listener cannot understand what the speakers talking about or it may disturb others' understanding. According to Oxford Advanced English dictionary, "pronunciation is a way in which a language or a particular word or sound is spoken". English is a language that is not possessed only by one nation. English can be identified of one's nation language as it has differences in terms of vocabulary, spelling and pronunciation. We can pronounce/gra:s/ referred to British English or pronounce /græs/ referred to American English.

The teacher's first language makes them modify their accent in the classroom for the benefit of students. It is possible to do that, but teachers still need to know the variation of English. Those who are well informed to variations of English will be able to differ which accent that they find when they hear the model. And students can be informed by teachers about the variation of English. However, Kelly (2000:14) states that RP is still the target for Pronunciation, because of its traditional status, though that is slowly changing. In case of which model should be used in the classroom, it depends on the teacher as long as the teacher can know and use the target model. However, he should be informed the English variation. The teacher may highlight the differences between British and American pronunciation, for example. Teaching that, students will be able to broaden their knowledge of variation of English. Indonesian learners often face some difficulties in learning English, especially in its pronunciation system.

The students of spoken English or any other spoken language is faced at the out-set with difficulties of five kinds in the matter of pronunciation (Jones, 1972:2). They are as follows: he must learn to recognize readily and with certainly the various speech-sound occurring in the language, when he hears them pronounced. He must moreover learn to remember the acoustic qualities; he must learn to make the foreign sounds which his own organs of speech; he must learn to use those sounds in their proper places in connected speech; he must learn the proper usage in the matter of 'sounds attributes' or prodies as they often called (especially length, stress, and voice-pitch); and he must learn to contact sounds, i, e , to join each sound of sequence on to the next, and pronounce the complete sequence rapidly and without stumbling (Afifah, 2013:2). 


\section{B. -ed Ending}

“-ed Ending" in the Past Participle. All verbs have four principal parts. Those parts are the base form, the past form, the present participle, and the past participle. The past form of verbs includes regular verbs and irregular verbs. It can find -ed ending in the past form of regular verbs and past participle. There are some ways to use past participle, they are: with the perfect tenses; with the passive voiced; participial phrases; participial adjectives. - ed ending do not found in the past form of regular verbs and past participle, but also in adjectives. There is a large group of adjectives which can have an -ed or -ing ending. However, there is a significant difference between them. According to Redman (2001:64), found that "the -ing ending is used on adjectives which describe a person or thing or situation. Meanwhile, the -ed ending is used on adjectives which describe the effect this person, thing, or situation has on us. There is a large number of words in English that end with -ed as stated in the previous discussion. We can find words with -ed ending in the past forms and past participle forms. The -ed ending is used to make the past tense and the past participle (Syafei, 1988:90). He adds that it has three pronunciation; [t] as in "picked"[pIkt], [d] as in "believed" [bIli:vd], and [Id] as in "needed" [ni:dId]. Moreover, he indicates the rules to pronounce the -ed ending as follows: a. [d] after all voiced consonants except [d], and after all vowel sounds as in planned [plænd], begged [begd], played [pleid]; b. [t] after all voiceless consonants except [t] as in stopped [stopt], kissed [kIst], picked [pIkt]; c. [id] after [d,t] as in needed [ni:dId], wanted [wontId].

While Syafei also focused on the pronunciation of -ed ending as the past tense and past participle forms, Bowler and Cunningham focus on -ed ending as adjective only. Just like when it occurs in past forms and past participle, -ed ending in adjective also has the three pronunciations: [t],[d], and [Id]. As that of Syafei's, the rules proposed by Bowler and Cunningham in pronouncing ed ending is more or less the same. The rules are as follows: a. When -ed follows the sound [d] or [t], it is pronounced [Id]; b. When ed follows a voiceless consonant apart from $[\mathrm{t}]\left([\mathrm{p}],[\mathrm{k}],[\mathrm{f}],[\mathrm{s}],[\theta],\left[\int\right],[\mathrm{t}]\right]$, it is pronounced $\left.[\mathrm{t}]\right)$; c. When -ed follows a vowel sound, or a voiced consonant sound apart from [d] ([b], [g], [v], [z], [ð], [3], [dz], [m], [n], [y], [l], [r], it is pronounced [d]). However, Bowler and Cunningham state that there are some adjectives which do not follow these rules. They have -ed endings which are pronounced [Id], such as in naked ['neikId], wicked ['wikId], etc. (Syafei, 1988:91)

\section{RESEARCH METHOD}

This research is including of qualitative research. Sugiyono's view point related to qualitative research is a research who has relation to post positivism philosophy, it is used to analyze the natural condition where the researchers are as a key. In getting sample, it can be used purposive and snowballs, its characteristic is inductive or qualitative, and the result of qualitative research more emphasizes the significance than the generalization (Sugiyono, 2015:15). This research refers to descriptive qualitative research. The researchers conducted a research to obtain data derived from the respondents. The selected research site was located in IAIN Bone, Bone regency, South Sulawesi, Indonesia. The researchers took object from the third semester students of English Study Program IAIN Bone.

The source of the data in this study was the subject of where the data can be obtained in this research the researcher uses two sources of data are: Primary Data, was collecting information for the specific purposes of their study. In essence, the questions are tailored to elicit the data that will help them with their study; and Secondary Data, there were several types of secondary data. They can include information from the national population census and other government information collected by Statistics Canada. One type of secondary data that's used increasingly is administrative data. While, the research collects the data by documentation.

Instrument of the research are the questions list of interview, the researchers arranged the questions list of interview. It was made to ease the implementation of interview season; recorder, was needed to record the students' voice. Thus, the researchers got the explanation clearly; and test, was given to the students as like reading test to know the students' ability in pronouncing -ed ending words.

Technique of collecting data, in conducting a research, some steps were required to be done in clear chronological order. In this study there were several steps to collect the data, namely observation. The 
purpose of doing this observation was to know the students' ability in pronouncing -ed ending; In depth interview, in order to avoid the ambiguous explanation, the researcher did in-depth Interview and chose an open guided interview; Documentation, to support the activities of observation the researcher used picture as prove that every steps was running well; and Recorder, was used to record the student's voice while doing the depth interview.

Technique of data analysis, the qualitative data analysis suits this research is from punch. He describes that there are three major components of qualitative data analysis are data reduction, data display and data verification (Punch, 2009). The explanation of the main components is explained as follows:

- Data Reduction

Reduction data occurs continually throughout the analysis. It is not something separate from the analysis, it is part of the analysis. In the early stages, it happens through editing, segmenting and summarizing the data. In the middle stages, it happens through coding and memoing, and associated activities such as finding themes, clusters and patterns. In the later stages, it happens through conceptualizing and explaining. Since developing abstract concepts is also a way of reducing the data.

- Data Display

Display data organizes compress and assemble information. Because qualitative data are typically voluminous, bulky and dispersed, displays help at all stages in the analysis. Miles and Huberman regard displays an essential. Often using the phrase 'You know what you display' they have no doubt that better displays are a major avenue to valid qualitative analysis. There are many different ways of displaying data- graphs, charts, networks diagrams of different types and any way that moves the analysis forward is appropriate. Displays are used at all stages, since they enable data to be organized and summarize. They show what stage the analysis has reached and they are basis for further analysis.

\section{- Data Verification}

The reasons for reducing and displaying data are to assist in drawing conclusions. While drawing conclusions logically follows reduction and display of data, in fact it takes place more or less concurrently with them. Thus possible conclusions may be noted early in the analysis, but they may be vague and ill-formed at this stage. They are held tentative pending further work and sharpened during it. They are not finalized until all the data are in, and have been analyzed. Conclusions will be in the form propositions, and once they have been drawn, they need to be verified.

\section{FINDING AND DISCUSSION}

This focuses on data analysis of the research about students' problem in pronouncing Ed-ending and focuses on discussion of the data of result finding. The result of the problem statement consist of observation and interview. Data analysis describes about the students' problem in pronouncing Ed-ending to answer the problem statement of the research. Based on the instrument of the research that the findings of the students' problems was found by using observation and interview. The observation described about the students' ability in pronouncing Ed-ending and the interview was used to know the students' problem in pronouncing Ed-ending.

\section{A. Observation}

The students as the object of this researcher were observed by the researcher directly in the location to describe the students' problem in pronouncing Ed-ending. The research did visibly, it means that researcher introduced herself and her research. The object of the research was the the third semester students of IAIN Bone, consist of five students. And the result of the observation are 


\section{Student one:}

The result of the observation, student was able to come forward and read the story that had been prepared by the researher, and started to read some words about the -ed ending. Here is the transcript;

I searched (/serchid/) other ideas from internet. Yap, I googled it. I watched (/watchid/) tutorial videos and read many art blogs.

My parents helped (/helpid/) me to prepare the materials. . Papers were rolled, shaped (/shapid/ ) and glued together to create decorative designs.

Based on the transcript above, the researcher can conclude that the student could not pronounce the -ed ending words correctly. There were some words which final of $t$, but the student pronounce them with wrong pronunciation, for example "searched, watched, helped, shaped" the correct pronunciation is /s3 : $\mathrm{t} f$ /, /wa:t5/,/helpt//ferpt/ the student pronounces the words with /id/ pronunciation. It shows that the student could not differentiate those words

\section{Student two:}

The result of the observation, student was able to come forward and read the story that had been prepared by the researcher. The student also able to read some word of -ed ending, but the student could not pronounce them correctly. Here is the transcript ;

I searched ( /serchid/) other ideas from internet. Yap, I googled (/googlt/) it. I watched ( /watchid/) tutorial videos and read many art blogs.

My parents helped ( /helpid/) me to prepare the materials. My siblings joined me on the third day. Then, my siblings and I made paper crafts from used newspapers and magazines. Papers were rolled, shaped ( /sheipid/ )and glued together to create decorative designs.

Based on the transcript above, the researcher can conclude that the student could not pronounce the -ed ending words correctly. There were some words which final $\mathrm{d}$ and $\mathrm{t}$, but the student could not differentiate them and there were some words that the student could mention at all. For example "searched, watched,

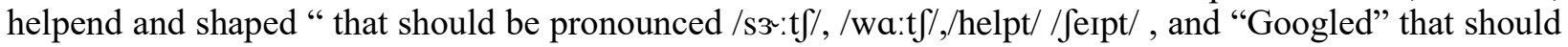
be pronounced'gu:.. ` $^{2} \mathrm{~d} /$, but the student pronounces it with final $/ \mathrm{t} /$.

\section{Student three:}

the result of the observation, student was able to come forward and read the story that had been prepared by the researher, and started to read some words about the -ed ending. Here is the transcript;

I searched (/serched/) other ideas from internet. Yap, I googled (/googlid/) it. I watched (/ watchid / ) tutorial videos and read many art blogs.

My parents helped (/helpid/) me to prepare the materials. Papers were rolled, shaped (/sheipid/) and glued together to create decorative designs. Many beautiful crafts were created.

Based on the transcript above, the researcher can conclude that the student had same problem from the previous student she could not pronounce the -ed ending words correctly. And There were some words which final - $d$ and -t, but the student could not differentiate them. For example example "searched, watched, helped, shaped" the correct pronunciation is /sz: tf/, /wa:t5/,/helpt// eipt/ the student pronounces the words with /id/ pronunciation. and "Googled" that should be pronounced /'gu:.g ${ }^{\ni} \mathrm{ld} /$, but the student pronounces it with final /id/. 


\section{Student four:}

the result of the observation, student was able to come forward and read the story that had been prepared by the researher, and started to read some words about the -ed ending. Here is the transcript;

I searched ( / serchid / ) other ideas from internet. Yap, I googled ( / googlid / ) it. I watched (/watched /) tutorial videos and read many art blogs.

My parents helped ( / helpid / ) me to prepare the materials. They also gave me money to buy things I needed. On the first day, I painted ( / peinted / ) /peintid/on some_rocks. Papers were rolled, shaped ( / sheipid /) and glued ( / gluid / ) together to create decorative designs.

Based on the transcript above, the researcher can conclude that the student had a really big problem in pronouncing -ed ending words. because based on the result above, almost all the words of -ed ending were pronounced uncorrectly. For example example "searched, watched, helped, shaped" the correct pronunciation is /s3: $\mathrm{t} /$ /, /wa: $\mathrm{t} /$ /,/helpt/ / eerpt/ the student pronounces the words with /id/ pronunciation. "Googled" that should be pronounced 'gu:.. $\mathrm{g}^{2} \mathrm{ld} /$, but the student pronounces it with final /id/. And glued that should be pronounced /glu:d/, but the student pronounce it with final /id/, "painted" that should be pronouced /perntid/ but the student pronounces it with final /ed/.

\section{Student five:}

the result of the observation, student was able to come forward and read the story that had been prepared by the researher, and started to read some words about the -ed ending. Here is the transcript;

I searched ( / sheipid / ) other ideas from internet. Yap, I googled ( /googlid / ) it. I watched ( / watchid / ) tutorial videos and read many art blogs.

My parents helped ( / helpid / ) me to prepare the materials. They also gave me money to buy things I needed ( / needt / ) /'ni..did. On the first day, I painted ( /paint /) on some rocks. People call it rock art. It was so fun. My siblings joined ( / joinid / ) me on the third day. Then, my siblings and I made paper crafts from used (/ usid / ) /ju:st/ newspapers and magazines. Papers were rolled, shaped ( / sheipid ) and glued together to create decorative designs. Many beautiful crafts were created( / kri'erted/ ).

Based on the transcript above, the researcher can conclude that the student had problem in pronouncing all the -ed ending words which final of -ed, -t, and -d.. because based on the result above, almost all the words of -ed ending were pronounced uncorrectly. For example example "searched, watched, helped, shaped used" the correct pronunciation is /s3: $\mathrm{t} / \mathrm{l}$, /wa:t $\mathrm{f} /, / \mathrm{helpt} / / \mathrm{ferpt} / \mathrm{ju}: \mathrm{st} /$, the student pronounces the words with /id/ pronunciation. "Googled" that should be pronounced 'gu:.gəld/, but the student pronounces it with final /id/. "needed, joined" that should be pronounced /'ni..did/,/dzomid/ but the student pronounces it with final /t/. "painted" and "created" that should be pronouced /perntid//kri' ertid/., but the student pronounces it with final /ed/.

\section{B. Interview}

Students problem as the object of the research have to be known by their selves directly. Exactly, it is needed something as the way that can give more information about their problems. Interviewing conducted in this research in collecting the data. This research needs concrete interaction and giving interview process flexibly to the students. So, this research uses an close guided interview. The result of the interview found that the problems are ;

1) The students could not differentiate the -ed ending words

One of the students' problems was they did not know how to differentiate the ed-ending words. howerver the pronunciation of -ed ending sometimes causes problems for non native speakers because it can be pronounced in three different ways as ; /id/, as/ $\mathrm{t} /$ or as / $\mathrm{d} /$. Here is the transcript: 
"I don't know how to mention it kak, I don't know which one is pronounce ed or d saja or t, so difficult, I don't know how to differentiate them. And the problem really make me can not speak english well and fluently."

This statement also is supported by other students who said "I am really difficult to mention the words, and sometimes I find some words and I don't know I have to pronounce the with final d,ed, or t"

Based on the result of the interview above, it can be conluded that one of the students' problems in pronouncing -ed ending is " the students could not differentiate the -ed ending words"

\section{2) The students have lack knowledge about-ed ending}

The students have learnt phonetic and phonology before, but they never practiced with their friends in the classrom. They also seldom to read a book related to -ed ending words then make them are confused to pronounce the -ed ending words. It can be described in the following of the result of interview. Here are the transcript:

"when I want to pronounce it, I really don't know to mention the words, I don't know anything about -ed ending because I seldom to practice with my friends and the problems really make me to speak English fluently"

The statement above is also supported by another student who said "I don't know to pronounce it, and I never practice to speak with my friends about -ed ending words, I never read a book abouted ending, so it makes me difficult to speak English fluently"

Based on the result of interview above, the researcher can conlude that one of the students' problem in pronouncing -ed ending is "the students have lack knowledge about -ed ending".

According the result of the interview of some students above, it can be identified that all the students knew about -ed ending and they could give some exmple of -ed ending words but they have the same problem when they want to mention the words correctly. Most of students did not know the theory and they did not know to practice the words, and it makes them difficult when they speak and find the -ed ending words. And also the teacher or lecturer did not give all the students some clear explanation how to pronounce the words, then make students are confused when they find some -ed ending words such as; walked, washed, hoped, and etc. lack of knowledge also becomes one of some students' problem in pronouncing -ed ending. They have learnt phonetic and phonology but they never brush up the lesso that has been given from the lecturer. They also never read a book about -ed ending and seldom to practice the words in their daily, then make their tongues are numb to pronounce those words.

According to the results which have been presented, it shows that most of the students which became the sample in this reseach found many difficulties to pronounce the -ed ending words. The observation which was done by the researcher confirmed it. The students mostly have basic skill in English, moreover, they have studied Phonetic and Phonology subject. There are some factors affecting this problem. The factors are explained clearly as follows:

1) English is not the students' mother language.

To ease to speak a language, it should be familiar with the speakers; moreover, it is used widely in the environment whether it is in school, family, and playground. The students that have become the researcher's objectre not the native speakers of English. So, the trouble to differentiate -ed ending is understandable. Since childhood, the babies have imitated what their parents mention. Therefore, the articulation has been deeply implanted in him as parts of his habits. 
2) English has its own pronunciation rules especially for-ed Ending

In English, there are some pronunciation rules that should be comprehended. For the foreigners, they should take some time not only to understand the rules but also to practice them. Indirectly, this condition affects their ability to differentiate the words with -ed ending.

3) The motivation of pronouncing the words correctly affect the students' skill.

The students' motivation to use the correct pronunciation also give the contribution to this problem. They only get the pronunciation lesson by studying in campus. Hence, the lesson does not fulfill their understanding of pronunciation especially for -ed ending. The students should motivate themselves to study -ed ending not only from lecture in campus but also from some references or English courses.

4) The students get difficult to differentiate the final -ed

The students sometimes get difficult to pronounce the -ed ending words because the student can not differentiate the words. however, the pronunciation of -ed ending words sometimes cause the students are non native speakers. So it is difficult for the students to really good in pronunciation especially in pronouncing -ed ending words. because in pronouncing the -ed ending words have three different ways, there are ; id/, t /or d.

5) The student have lack of knowledge about-ed ending

One of the students' problem in pronouncing -ed ending is because the students have lack of knowledge about -ed ending. The students have learnt about phonetic and phonology before, but they never brushed up the material that they have got when they study about -ed ending. So, when the students get words that should be pronounced of $\mathrm{id} / \mathrm{d} / \mathrm{t}$. the students feel difficult to pronounce them all. The students also never read some books related of pronunciation, especially about how to pronounce -ed ending words.

6) The students just know the theory but never practice the -ed ending words

Sometimes, there are some students who just know the theory well. They know which one is final $\mathrm{id} / \mathrm{d} / \mathrm{or} \mathrm{t}$. but because they never practice to pronounce the -ed ending words or just practice with their friends by using conversation. It makes their tongue so strange to mention the words. so the result, they just know the theory well but when they pronounce the -ed ending words, they get wrong.

\section{7) The students' problem in pronouncing - ed ending}

After the resarcher did an observation and interview to the students. The researcher can say that the students got some problems in pronouncing -ed ending. The first problem is the students could not differentiate the words which final of /ed/d/ or t. for example "searched that should be pronounce with final of /t/ but most of students pronounced it uncorrectly, some students pronounce it with final /d/ and other students pronounce it with final of /id/. The students also have lack of knowledge -ed ending about -ed ending. From the result of interview, there were some students said that they do not know about -ed ending words, they also never practiced to pronounce -ed ending words with their friends or just practice by themselves. So, it makes them feel difficult to pronounce the -ed ending words when they find such a case when they are speaking in their daily life.

\section{CONCLUSION}

Based on the identification, it was found that the students' correct pronunciation were about half of the total pronunciations of -ed ending tested. It showed that the students' ability in pronouncing -ed ending was still poor. The result showed that most of the students were difficult to pronounce the -ed ending words correctly. They did not know how to pronounce and differentiate the words with final -ed, -d, or -t. The problems encountered by the students in pronouncing -ed ending caused by their lack of knowledge of the pronunciation of -ed ending. It is also possible that they do not know the theory well, and they are not able to practice it orally. 


\section{REFERENCES}

Afifah, Lutfia. (2013)“ An Analysis of Student's Pronunciation Errors in Readig Texts At The Sixth Grade Students of SDN 3 Cisauhen bandung Barat”.

Dewi, Anggun Kusuma. (2009) "Pronunciation Problems Faced by The English Department Students in Pronouncing - ed Ending (A Case Study of The Sixth Semester Students of The English Department of UNNES Academic Year of 2008/2009), (unpublished thesis).

Hakim, M. Arif Rahman. (2012). An Analysis Of Phonetics b, d, g, j, - and ð into English pronunciation for Java Students ( A Study On Java Students at English Department on STAIN Bengkulu Academic Year 2011-2012). International Journal of Humanities and Social Science, Vol. 2, No. 20.

Jones, Daniel. (1972). “An Outline of English Phonetics, Cambridge University Press,

Kelly, Gerald. (2000) “How to Teach Pronunciation (Essex Pearson Education)”.

Murcia, M.C.et.al. (1996). “Teaching Pronunciation: A Reference for Teachers of English to Speakers of Other Languages”. Cambridge University Press.

Muslimah, Nurul. (2008) 'The Students' Ability in Pronouncing Verb Inflectional Endings at The Eleventh Grade of MAN 3 Rantau Academic Year 2012/2013” (unpublished thesis).

Oxford, Learners' Pocket Dictionary(Fourt Edition ; Oxford University Press).

Punch. (2009) “Introduction to Research Methods in Education”, Los Angeles: Sage Publication.

Ramelan. (1999) “English Phonetic”, Semarang: UNNES Press

Redman, Stuart. (2001). "English Vocabulary in Use: Pre intermadiate and Intermediate”, Jakarta Erlangga.

Setter, J. (2008). Theories and approaches in English pronunciation. InR. Monroy \& A. Sánchez (Eds), 25 years of applied linguistics in Spain: Milestones and challenges (pp. 447-457). Murcia, Spain: Universidad de Murcia, Servicio de Publacaiaones.

Sugiyono. (2015) "Metode Penelitian Pendidikan, Bandung: Alfabeta”.

Syafei, Anas. (1988). English Pronounciation Theory and Practice. Jakarta. Depdikbud Direktorat Jendral Pendidikan Tinggi P2LPTK.

Tlazalo Tejeda, A. C., \& Basurto Santos, N. M. (2014). Pronunciation instruction and students' practice to develop their confidence in EFL oral skills. PROFILE Issues in Teachers' Professional Development, 16(2), 151-170.

Yates, Linda. (2002). Fact Sheet-What is Pronunciation? Sydney: AMEP Research Centre 